Meta

Journal des traducteurs

Translators' Journal

\title{
Translation and Intercultural Education
}

\section{Isabel Pascua}

Volume 48, numéro 1-2, mai 2003

Traduction pour les enfants

Translation for children

URI : https://id.erudit.org/iderudit/006974ar

DOI : https://doi.org/10.7202/006974ar

Aller au sommaire du numéro

Éditeur(s)

Les Presses de l'Université de Montréal

ISSN

0026-0452 (imprimé)

1492-1421 (numérique)

Découvrir la revue

Citer cet article

Pascua, I. (2003). Translation and Intercultural Education. Meta, 48(1-2),

276-284. https://doi.org/10.7202/006974ar

\section{Résumé de l'article}

Dans cette étude, on vise deux objectifs : dans un premier temps, la littérature enfantine canadienne et, dans un deuxième temps, la réception de cette littérature dans les écoles espagnoles, par l'intermédiaire des traductions et dans le cadre d'une éducation interculturelle.

Dans la première partie, on précise ce qu'on entend par éducation interculturelle et dans la deuxième, on étudie le nouveau rôle joué par le traducteur qui ne travaille pas seulement avec deux langues et deux cultures, mais avec plusieurs cultures écrites dans une même langue (anglais), dans un même pays (Canada) et traduites dans une autre langue (espagnol). Par conséquent, on retrouve un nouveau traducteur pour une nouvelle littérature et un nouveau lecteur. 


\title{
Translation and Intercultural Education
}

\author{
ISABEL PASCUA \\ Universidad Las Palmas de Gran Canaria, Las Palmas, Spain \\ ipascua@sinf.ulpgc.es
}

\begin{abstract}
RÉSUMÉ
Dans cette étude, on vise deux objectifs: dans un premier temps, la littérature enfantine canadienne et, dans un deuxième temps, la réception de cette littérature dans les écoles espagnoles, par l'intermédiaire des traductions et dans le cadre d'une éducation interculturelle.

Dans la première partie, on précise ce qu'on entend par éducation interculturelle et dans la deuxième, on étudie le nouveau rôle joué par le traducteur qui ne travaille pas seulement avec deux langues et deux cultures, mais avec plusieurs cultures écrites dans une même langue (anglais), dans un même pays (Canada) et traduites dans une autre langue (espagnol). Par conséquent, on retrouve un nouveau traducteur pour une nouvelle littérature et un nouveau lecteur.
\end{abstract}

\begin{abstract}
This paper deals with translated Canadian multicultural literature written for children and its reception in an intercultural education context in Spanish schools. In the first part of the paper I will introduce intercultural education. In the second part, I will examine the role of the translator working in a multicultural environment where texts are written in one language (English) in one country (Canada), then translated into another language (Spanish) and published in Spain. I will also look at the reception of these translations as well as the strategies translators should use to maintain the otherness of the original texts.
\end{abstract}

\section{MOTS-CLÉS/KEYWORDS}

multicultural literature for children, intercultural education, foreignization, Canada

\section{Introduction}

The purpose of this paper is to share the results of a research project I am conducting with a group of experts on children's literature and translation. The aim of the project is to use translated children's literature, mainly Canadian multicultural literature in Spanish schools, in order to fill a void which exists in Spanish children's literature.

Why multicultural stories? Because of the new phenomenon of immigration in Spain, and particularly in my region, where a new multicultural and multiracial identity is emerging. The group of experts involved in the project firmly believes that a new educational policy is needed to overcome so much hostility toward the foreign, the strange, "the other," and that this policy should be framed within an intercultural education context.

My role within the project is (1) to choose some multicultural stories written in one language, English, by authors from different ethnic groups living in the same country, Canada; (2) to translate the stories into Spanish, paying attention to the cultural references and the strategies chosen to maintain the otherness of the original 
stories, in order to use those translated stories within an intercultural education context. That is why in the first part of the paper I will concentrate on multiculturalism and interculturalism, following the experiences of Canada and some European countries. In the second part, I will illustrate some translation difficulties I encountered and how I resolved them.

\section{Multicultural and intercultural education}

Nowadays, multicultural studies are on the rise in Spain, just as they are in other countries, where immigration has engendered both a multicultural and multilingual society. Although during the last years these studies in Spain were considered mainly from a social and political perspective, they are having certain repercussions on literary and educational fields as well.

As an academic, translator and educator, I am interested in looking closely at multicultural children's literature and its translation because translation is an act of intercultural communication. This interest gave rise to this educational project aimed at our environment, where young Spanish readers, through translated children's stories, can get to know other children from different cultures from other parts of the world and thus become multicultural readers. It is a way of helping to educate our children to tolerate and respect children from other places attending schools in our own countries. All this implies preparing our future generations to become citizens of a new society where it is possible "to distinguish without discriminating."

One of the key issues in the project is to disseminate "multicultural" literature and, as a translator and translator trainer, "intercultural translation" for a new group of recipients.

Let me first define what I understand by multiculturalism, interculturalism and pluralism. According to Canadian experts, multiculturalism is based on the belief that cultural diversity is beneficial for any society. Thus the philosophy behind it consists of creating a suitable environment where different cultures respect, value and mutually support one another. On the other hand, cultural pluralism refers to a society where members from each and every ethno- cultural group uphold their own customs and traditions. Another interesting point concerning these terms is that made by Giovanni Sartori in his latest controversial book Pluralismo, multiculturalismo e estranei (2001). According to him, multiculturalism, as applied in the USA and which resulted in the unsuccessful experiment called the "melting pot," highlighted differences between cultures and ethnic groups, producing closed circles within society. However, pluralism is based on tolerance and recognizing the value of diversity. If what multiculturalism set out to achieve was an integration with diverse characteristics, what it has actually accomplished has been a total multi-ethnic disintegration. Pluralism encourages an unprejudiced society, showing consideration for the multicultural society and guaranteeing stability in "inter-cultures." According to Sartori, multiculturalists claim recognition, and yet, seem to forget that recognizing should be reciprocal.

Nevertheless, it should be emphasized here that these views refer to social and political fields, whereas in the educational context, these distinctions although not clear are ever present. For instance, Sánchez Fernández (1996) believes that the term "intercultural" suggests a huge step forward, towards the acknowledgement of the 
contributions made by the different groups, and supports the idea that these contributions be incorporated in the school curriculum.

The following question needs to be asked: how has intercultural education been implemented in those countries which are already ahead of us in this particular field? Despite the fact that in some European countries, such as Holland, Belgium and Great Britain, education policies aimed at immigrant children have been developed, intercultural education has not been dealt with to any great degree, nor has it had the success which the policies in North America have had.

The issue of multiculturalism arose in Canada in an attempt to resolve problems caused by massive immigration in the twentieth century. Canadians even maintain that the very term originated in their country due to the important influence of immigration on Canada throughout the country's history. Indeed, in the 1970's, this issue was already being discussed and came into being in July 1988, when Parliament in Ottawa passed the Canadian Multiculturalism Act. Subsequently, Canada became the very first country to acknowledge and encourage cultural and racial diversity via legislation (Hutcheon/ Richmon 1990: 371).

Although the term "mosaic" does not seem as radical as that of the earlier "melting pot," it has been analyzed and criticized especially by those Canadian authors who have emerged as a result of the Diaspora. For instance, Dieter Petzold believes that both terms refer to the same reality: a unit divided into separate segments. He believes that this unit in both metaphors should be defined more coherently and that this lack of definition is what leads to the myth that multiculturalism is the universal cure, the "magic formula capable of solving all these problems" (1999: 178). Many authors and educators have pointed out that this is not a problem to be dealt with by enforcing a law. Furthermore, it is not a matter of folk songs and dances, customs and traditions or ethnic dishes, but one of human rights, mutual acceptance and respect.

The idea that multiculturalism is no magic formula is also present in the stories by the famous children's author, Paul Yee, a third generation Canadian. The author makes it quite apparent that the problem stems from racial discrimination. He admits that in his stories, there are underlying pedagogical messages, through which he wants to help the Canadian-Chinese community to grow spiritually by depicting the history all of them helped to shape in that country; he feels that on the other hand, ignoring the period of racism will not help the newcomer to create an identity for her/himself, nor help her/him to feel as Canadian as the white boy who plays in the same street, even if this white boy is a newcomer, too.

This is but one of the many questions and examples I have looked at in my project. Canada is a country of vast dimensions with a population of some 30 million inhabitants and seventy different ethnic groups speaking over sixty languages. This has called for a specific educational policy, and within that policy, children's literature plays a very prominent role. By means of this literature, an attempt has been made to achieve several objectives: to encourage these ethnic groups, coming into a new society, not to renounce their roots, but to maintain their customs and traditions from their country of origin, and to retain their ethnic identity. At the same time, they are prompted to take part in a new life at both local and national levels. This identity is shared with other ethnic groups who find themselves in a similar situation, and this helps create the mosaic of collaboration constituting the Canadian identity (Saltman 2001). 
In Spain, educators are learning through trial and effort, and have arrived at the conclusion that intercultural education requires different activities such as the incorporation of interculturalism in current curricular study plans in schools and preparation of class material at all levels. This is where writers and translators each have the opportunity of contributing to the project on intercultural education. What role would translators of children's literature play in this multi-intercultural education? What has been achieved up until now and what still remains to be done? And what resources are within reach?

Theoretically speaking, establishing a legal framework concerning this new type of education is essential, before it can be put into practice. Then activities related to customs, traditions, lifestyles, as well as literary and artistic expressions of diverse ethnic groups must all be incorporated into every school curriculum, especially languages, music and art. It is right here that translators come in, since children's literature is a vital resource when it comes to providing a pluralist, intercultural education.

I believe that this new reality has to be approached in two ways. In the first place, while not breaking away from their own language and culture, the newcomers may be encouraged to participate in activities where they look for and read tales in different languages spoken in different communities. These activities are mutually beneficial, as all the children belonging to the same class are aware of having something new in common, sharing a new language that they can use while learning more about the other children in the environment. All this can be achieved through the work of translators.

\section{Interculturalizing translation}

Translators' bilingualism has been discussed throughout the history of translation. Today, however, scholars in translation studies seem to take a greater interest in communication and culture than linguistic issues as such: translation is seen rather as action between cultures than between languages. Moreover, translators of children's literature are facing the new challenge of translating multicultural literature for children.

Up until today, students studying translation have been taught that as culture is the central issue in translating they should be not only bilingual but bicultural. However, the situation gets very complicated when working with multicultural literature written in a familiar language but situated in strange surroundings. For example, stories written in English, reflecting diverse cultures from the North Pole, the Caribbean Islands, China, Palestine or Latin America. Would this new situation imply that only a translator from Asia can translate stories about Asia, and only an expert on African culture is able to translate an African tale? What then should translators do about the true-to-life multiethnic "mosaic" of written stories coming from Canada? Should the translators familiarize themselves with all the far-away cultures of the original stories? For example, what should translators do with the stories by such Canadian authors as Tololwa Mollel (originally from Africa), Luis Garay (originally from Nicaragua), Paul Yee (a Canadian of third generation descent), Ricardo KeenDouglas (from the Caribbean Islands), Jan B. Waboose (American native Indian), Robert Munsch (born in USA) or even Margaret Atwood?

What kind of strategies should be used, when translating these stories into Spanish? And what would the reaction be to this multicultural literature in the new 
multiethnic Spain with so many different recipients? Here lies the greatest challenge of our project. How then should these stories be translated?

As my main task as a translator is to let my readers know more about the foreign and the "other," I would naturally opt for "foreignization": keeping the exotic and the unknown in the translated text. Keeping intercultural education in mind when translating for children it is important to maintain the "cultural references" of the original text, and pay attention to the issues of acceptability and readability. The translated text should not maintain the "linguistic discourse" of the original language as we have to pay attention to the future readers, the children. They will not like a text with strange-sounding sentences and complex grammatical structures. Different treatment should be given to those cultural markers which introduce Spanish readers to new worlds. Readers will understand that it is a foreign text and should "feel" that they are reading a translation if not only for the exotic names, places, food, clothes, customs, etc. (see Pascua 2000 and 2001). Unlike the norm in Spain a few decades ago, which required translated texts to "sound" very Spanish, this way of translating emphasizes the different - something essential on translating multicultural literature.

The translation, the recreation of the original text, covers acceptability, one of the most important requirements in translating books for children (see Puurtinen 1995). As Lefevere (1997) and Oittinen (2000) point out, translators are the authors of the translation, which is a new text for new readers. Translation, however, does not imply anarchy; the limits are set by the translation situation as well as the translators' own creativity. Translators enter into dialogue with not just the author of the original but also with themselves. This dialogue comprises several voices: the "you" of the author, the future child reader, as well as the translators' own child within, their childhood and adulthood experiences (see Oittinen 2000). Self-effacement can lead to the self-destruction of the translators. The limits are established in accordance with the text, the multicultural surroundings as well as the experience of the translators. This is not an easy task but it is the challenge which translators face when translating a new story in a new communicative situation.

Miguel Sáenz (1999), the acclaimed translator, expresses the need for new ways of translation in a multicultural environment. He points out that, in the end, it matters little if an image or metaphor is commonplace in Turkish or German or if it is included in the idiolect of a Turkish author who writes in German. What is really important is that the image is there and functions in the target language, like in Spanish in my case. This is another of the key issues in this project: how to find a solution to these new problems which translators are faced with when translating multicultural literature, and what strategies would have to be used.

Which stories should we choose for translation and teaching in an intercultural class? Although it is usually the publishers' editors who choose the texts to be translated, in the case of this particular research project, I chose the stories to be translated. Introducing new realities to target-language readers is not an easy task as the readers of the translations with multicultural backgrounds should also find the texts appealing. In other words, a happy balance between a commercial issue and educational policies needs to be struck. While reflecting the image of other literatures and cultures, we help to create the identity of the target culture, "a new and challenging multicultural identity." 
All cultures have stories and tales about their own history which have been handed down from generation to generation. Translators also come across contemporary authors relating myths and legends about their forefathers, their origins and everyday life. According to Carolina Valdivieso (1994), these stories open up new horizons about mankind and about its mutual roots and history, while underlining the unique characteristics of every human being. Canada is among those cultures that produce this kind of intercultural and multicultural literature. Canadian stories deal with issues relating to the Diaspora, the authors' feelings about being a foreigner and leading an everyday life, like playing in the park and going to school, in an environment with several ethnic groups. For these very reasons, the following Canadian stories have been selected:

1. Big Boy by Tololwa Mollel - a story based on African folklore, about a boy with extraordinary powers, which make him invincible. Using an old myth as the basis for his story, the author creates a contemporary tale about every-day life in Tanzania. Kiswahili words (the official language in Tanzania), which are explained in a short glossary at the back of the book, are used to add authenticity to the story.

2. The story of Firedancers by Jan B. Waboose is situated in the great prairies of Canada. The author, a member of the Bear Clan from northern Ontario, tells the story of a girl, named Fast One. In the story the girl's grandmother, Noko, takes her to dance around a fire in Smooth Rock, the magic island. On hearing the incessant sound of their moccasins as they dance, some of her ancestors appear as if by magic. The girl's grandfather and the girl's elders turn up to join them in the ceremonious dance.

3. Paul Yee's The Boy in the Attic is situated in the Far East. The story is about a boy called Kai-ming Wong and the misery and hardships he suffers from being uprooted. The boy feels lonely on leaving his country to start a new life with his parents in the New World. Everything is different there, even playing with the children in the street. Starting up a friendship with another boy, despite the fact that he is a ghost from the past, helps Kaiming and gives him the strength to overcome the difficult times.

4. In the tale of La Diablesse and the Baby, the author Richardo Keens-Douglas depicts the storytelling situation in the moonlight in his own country and thus popularizes Caribbean culture. The story, extracted from the oral tradition in the Caribbean, portrays the archetype of the she-devil, common to many civilizations under different names, such as the Pied Piper of Hamlin, the Ogre or the Bogeyman who comes in the night to take away the children who do not want to go to sleep.

5. In his story From Far Away, one of the most well known writers from Canada, Robert Munsch, gets even closer, to the problem of the Diaspora: the exodus, the arrival and the acculturation in a new country and language. What is fascinating about the story is the collaboration between the author and a seven-year-old girl Saoussan Asker, who writes letters to the author who in turn uses them as the basis for this amusing tale. The narrator is the girl and the narration is in the first person. This adds realism and clarity to the story which relates compelling events such as, the humiliation of not being able to understand the new customs. She perceives a simple paper skeleton at a Halloween party as the premonition of yet another war, just like the one she has escaped from.

6. The Long Road by the Nicaraguan author, Luis Garay, is set in what could be any little village in Latin America. The book tells us about José and his mother who have to escape, at the outbreak of civil war in their country. They need to travel long distances, always towards the north and under the cover of night, hiding from soldiers, sleeping in shelters for refugees and forever asking themselves what they will find in the next place they escape to. 
Cultural references usually pose greater difficulties for translators than mere linguistic problems, since translators have to overcome cultural barriers, a task at which they have to be more creators than transcribers (see Pascua/Marcelo 2000). In the end, I shall take a look at some difficulties encountered and their solutions.

In Big Boy, the story from Africa, I encountered cultural markers concerning the boys' names (Oli and Mbachu), the bird which grants wishes (Tunukiazawadi) and the African trees $(\mathrm{Kuyu})$, the meals (ugali) and the kinds of materials used in women's dresses or blankets (kanga). In this story, I decided to leave these features in their original form, as our intention is precisely one of proliferating these cultural references. Yet at the same time, willing to leave out the didactic function which is present in every story, I included a short glossary explaining the terms, like the one in the original book.

The Indian story Firedancers, proved problematic at some points, especially with regard to proper nouns such as the main character's name. The name given to the girl "Fast One" did have a very significant meaning: the girl is very active and always in a hurry, leaving her grandmother far behind. For example, there is a moment when grandmother has to tell her:

Original Text: "Slow down, Fast One," Noko shouts after me.

In this specific case, to keep the connotation of the girl's name, I opted for compensation by including a laconic expansion of the target text:

Target Text: "Ve más despacio, Fast One," gritó Noko detrás de mí. (Por eso me llaman Fast One, "La que va deprisa").

("Slow down Fast One," Noko shouts after me. That's why I'm called Fast One “The one who's always in a hurry." Backtranslation mine.)

In The Boy in the Attic, Paul Yee's story, there are two boys whose names indicate their origin: Kai-ming Wong and his friend, Benjamin. As a translator, I decided to leave them as they are. The cultural markers for the country's customs and traditions in the story proved to be very interesting. For instance, going to say goodbye to forefathers before departing for North America and taking them food is a very culturespecific issue. There are also a number of rituals which, as the author points out, have been banned across the country, China, for a long time. As a translator, I again felt that it would not be fair to miss the opportunity of broadening children's cultural knowledge and taking them on a "journey" to other parts of the world.

In Luis Garay's story, The Long Road, I encountered a different kind of problem altogether. Since the proper names are already in Spanish, the markers concerning Latin American culture are not as apparent to a Spanish reader as they obviously would be in the English version. For example, the boy's name is José; his uncle is "Uncle Ramón," his aunties are "tía Rosa" and "tía María," and his grandmother is "abuela." Here I used a compensating technique, and relied on the illustrations as part of the essential dialogue between both cultures, using information about the colours, the local lifestyle, the people's facial features and the multi-coloured clothes that South and Central Americans often wear. On this occasion too, I decided to keep the names unchanged. Another cultural marker which English readers would appreciate, but which Spanish readers would miss, is when the boy's mother or uncle call him "muchacho," in the English text. Since this is a term commonly used in the 
Spanish culture, I modified it into "chiquito" or "chamaco," terms which are clearly Latin American. I also changed the word "dinero," meaning "money," into "plata," the Latin American equivalent. Another alternative would have been to set the story in Latin America, but avoiding the name of any one, particular country.

\section{Conclusion}

After translating these and other multicultural stories, I believe that ultimately it matters little if an image is commonplace in China, Palestine or Tanzania, or if it is included in the idiolect of a Latin American author who writes in English or in Spanish. What is really important is that the image is there, and functions in the target language, in Spanish in my case. Related to the strategies on translating cultural references within multicultural texts, I believe that the first thing translators should take into account is the reader and the reader response. Secondly, it is important to consider, why these texts are translated.

Together with the other members of the project, I hope that by translating these texts we have helped to fill some cultural gaps and to create a new polysystem for Spanish children's literature. We also believe that these and other translations will encourage Spanish or immigrant authors to write original multicultural stories in Spanish, following the experiences of Canada and other European countries.

Taking these multicultural translations to Spanish schools provides the children with intercultural understanding, constructing bridges while dismantling barriers between different peoples and their cultures. Our children will learn more about what the "others" are like and get to know them better. Just in the same way, newcomers and children from immigrant families will get to know our children, too, but it is always a give-and-take situation. Our aim, in this project, is to avoid the difficult situation that the two children in Julie Lawson's White Jade Tiger (1993) were faced with:

"Jasmine was indignant about racial slurs directed against her and her friend Keung. She took a deep breath, fighting for control. She wanted to lash out at them, strike them down with the force of her words. But something more than rage smouldered inside.

- "I know it hurts," Keung said as the men walked away [...]

- "But why do they talk like that? I don't get it. They don't even know us."

- "That's why. It's because they don't know us that they talk like that."

\section{REFERENCES}

Alvarez, R. and C.A. Vidal (1997): Translation, Power and Subversion. Clevedon: Multilingual Matters.

Hutcheon, L. and M. Richmon (1990): Other Solitudes: Canadian Multicultural Fictions. Toronto: OUP.

Lefevere, A. (1997): "Translation and Canon Formation: Nine Decades of Drama in the States" in R. Alvarez and C. A. Vidal (eds.), pp. 138-155.

Mcgillis, R. (ed) (1999): Voices of the Other. Children's Literature and the Postcolonial Context. New York: Garland.

Oittinen, R. (2000): Translating for Children. New York: Garland.

Pascua, I. and S. Bravo (1999): "El traductor: intermediario visible" in A. Alvarez, and A. Fernández (eds.), Anovar, anosar, Volume III, pp. 163-168. Vigo: Publicacións da Universidade de Vigo. 
Pascua, I. (2001): “Problems of Translating Canonized Texts in Children's Literature: The Case of Alice." Translation and Meaning 5, pp. 299-307.

Pascua, I. and G. Marcelo (2000): "La traducción de la LIJ." CLIJ, No 123, pp. 30-36.

PAscua, I. (2000): "The Interventionism on Translating Cultural References." Conference presented in New York University.

Petzold, D. (1999): "Multiculturalism in Canadian Children's Books: The Embarrasments of History," in Roderick McGillis (ed), pp. 177-192. New York: Garland.

Puurtinen, T. (1995): Linguistic Acceptability in Translated Children's Literature. Joensuu: Publications in the Humanities.

SÁENZ, M. (1999): "La traducción nueva de una nueva literatura” en Hernando de Larramendi, Miguel/Arias, Juan Pablo (eds.) Traducción, emigración y culturas, pp.175-178. Cuenca: Ediciones Universidad Castilla-La Mancha.

Saltman, J. (2001): "A Mosaic, not a Melting Pot...” Article presented in the I International Interdisciplinary Conference at the University of Reading.

SÁNCHEZ FernÁndez, S. (1996): "Educación multicultural: posibilidades en la práctica” en J.A. Ortega Carrillo (ed), Educación multicultural para la tolerancia y la paz, pp. 99-118. Granada: Grupo Editorial Universitario.

SArtori, G. (2001): Pluralismo, multiculturalismo e estranei. (Spanish translation: La sociedad multiétnica. y extranjeros, M. A. Ruiz de Arzúa. Barcelona: Taurus).

Valdivieso, C. and C. Beuchat (1994): “¿Por qué traducir libros para niños?” Revista Universitaria, $\mathrm{N}^{\mathrm{a}}$ 44, pp. 6-10. Pontificia Universidad Católica de Chile.

Venuti, L. (1995): The Translator's Invisibility. A History of Translation. London: Routledge.

\section{Multicultural stories}

Garay, L. (1997): The Long Road. Toronto: Tundra Books.

Keens-Douglas, R. (1994): La Diablesse and the Baby. Manitoba: D.W. Friesen \& Sons.

Lawson, J. (1993): White Jade Tiger. Victoria: Beach Holme.

Mollel, T. (1995): Big Boy. New York: Clarion Books.

Munsch, R. (1995): From Far Away. Toronto: Annick Press.

Yee, P. (1998): The Boy in the Attic. Toronto: Groundwood Books.

Waboose, J. B. (1999): Firedancers. Toronto: Stoddart Publishing Co. 